\title{
PHYSICAL CULTURE IN LIFE OF EASTERN-EUROPEAN REGION STUDENTS: MODERN STATE AND PROSPECTS OF DEVELOPMENT
}

Iermakov S.S., Cieślicka Mirosława, Muszkieta Radosław

Kazimierz Wielki University in Bydgoszcz, Poland

\begin{abstract}
Purpose: analysis of researches on physical culture problems among students in countries of Easter-European region (2013-2015). Material: As sources of information we chose data base of Russia, Poland and Ukraine. Besides, we used sites of the most known journals of Easter-European region. When choosing journals we based on rating of Russia (RISC), Poland (Index Copernicus) and Ukraine (bibliometryka of Ukrainian science) data bases. Results: thematic focus of researches on different physical education, sports and students health aspects was determined. The promising directions of researches are as follows: re-organization of system of students' physical education; interconnection of life quality and organism's resistance to environmental impacts; dependence of students' motor functioning on bad habits' presence; determination of factors, facilitating motivation for sport games in system of students' health related trainings; perceiving of life quality by disabled students; competence and professional skillfulness of specialists in physical culture and sports. Conclusions: it is recommended to use new, attractive forms of students' motor functioning. It is necessary to regulate students' motor functioning, considering motivation for success and for avoiding failures as well as to increase students' psycho-physiological stresses' resistance and to form students' culture of health.
\end{abstract}

Key words: student, health, physical culture, motivation, physical education.

\section{Introduction}

Practical realization of different scientific projects is important direction of physical culture and sports development in educational establishments. Some of such projects are implemented with governmental financial support. But main part of the projects is realized as initiative of educational establishments' teachers. All these, taken together, create certain scientific-research medium, which facilitates progress of physical culture - sports activity in educational establishments. Searching of ways to improve students' health, development of some kinds of sports, creation of favorable conditions for formation of youth's positive attitude to healthy life style, training of professional-applied skills of future specialists and other can be considered to be the main purpose of such researches. Demand in such works is conditioned by negative tendencies to worsening of students' health. Such tendencies are characteristic for all countries of EasternEuropean region. Even in more developed countries of the region (for example in Poland) there is observed the same trend to worsening of students' health. Alongside with it, the countries of this region have many common problems, which concern development of physical culture and sports in youth medium.

It is necessary to note that countries of Eastern-European region (Ukraine, Poland, Russia, Belarus and Moldova) have equal climatic and geographic conditions. More than half of Ukrainian and Belarus territory, northern-eastern part of Poland and western part of Russia are still polluted with radiation, resulted from the accident on nuclear power plant (Ukraine, Chernobyl, 1986). This accident's after-effects have being continued to negatively influence on youth's health that requires consolidation of these countries' scientific researches in this direction. It pre-determines demand in coordination of appropriate scientific researches of scientists of these countries. All these, taken together, mark out Eastern-European countries from other countries of Europe.

Sports' development in students' medium of these countries takes place in close regional frontier cooperation of universities, institutes and academies. Characteristic feature of this region is presence of physical education departments in structure of higher educational establishments (with staff from 5 to 70 workers): approximately 300 departments in Ukraine, Poland, Russia and a little less in Belarus and Moldova. These educational establishments have discipline "Physical education" in their curriculums. In most of educational establishments this discipline is compulsory (2-4 hours a week). Now there appears a trend to making this discipline an optional one (Poland, Ukraine, Moldova and partially in Russia and Belarus). Besides, distinctive peculiarity of this region's countries is practice to conduct physical education classes, depending on students' health and their division into three health groups:

1) Main health group (consists of students, having no health problems);

2) Preparatory health group (students with insignificant health disorders); Подготовительная группа (студенты с незначительными отклонениями в уровне здоровья);

3) Special health group, consisting of students with disorders of health. From this group, the group of therapeutic physical culture is formed for students with pathologies and disabled students.

The countries of Eastern-European region have approximately equal system of coaches and teachers' training. This training if mainly conducted at faculties (or institutes) of physical education of pedagogic universities (approximately 15 in every country) and in specialized educational establishments of physical culture profile (approximately 6 in every

(C) lermakov S.S., Cieślicka Mirosława,

Muszkieta Radosław, 2015

http://dx.doi.org/10.15561/20755279.2015.0603 
country). The largest technical universities in these countries also deal with training of coaches, physical culture instructors and teachers (approximately 5 in every country). In sport competitions these educational establishments seriously compete with specialized physical culture educational establishments. Distinctive feature of this region's countries is two-step preparation of scientific staff: candidate of sciences $(\mathrm{PhD})$ and doctor of sciences ( $\mathrm{PhD}$ professor).

Finally, countries of Eastern-European region have the same problems in students' physical education, in protection and improvement of heir health, development of sports, training of scientific staff and other. Increased radiation pollution forces the scientists of these countries to search solution of problem of students' health improvement and protection. Scientific researches in these directions often duplicate each other. It results in unjustified financial losses and ineffective researchers' work in this countries. It should be noted that in this region Russian language is used: to large extent in Russia, Belarus and Ukraine and to less extent in Poland. It permits for most of scientists to communicate and present their works in easy to understand for them language. In this region there appear positive tendencies to use English in scientific sphere of educational establishments. That is why demand in concentration and coordination of scientific results of Easter-European scientists in solution of physical culture and sports problems in students' medium is evident.

Recent years researches, dealt with students' life quality and health, development of physical culture and sports in educational establishments, have been being oriented more on solution of applied tasks. Analysis of thematic focus of the researches witnesses about presence of same problems in countries of Eastern-European region in educational establishments' physical culture - sport functioning: Russia [51, 54, 55, 78, 82, 88, 100, 182 et al.); Ukraine (2-4, 86, 87, 103, 142-146, 152, 162, 189-191 и другие); Польша (65-67, 130, 147-149, 151, 157, 159-161 и другие); Belarus (50, 101, 111 et al.). It can be added with researches of scientists from neighboring countries: Lithuania (211). The authors researched wide circle of problems, which are characteristic for educational establishments of their countries and for all Eastern-European region. Most of information is concentrated in several data bases: Index Copernicus (Poland) RISC (Russia), National library of Ukraine (Ukraine). The other portion is elucidated in journals of these countries. Such distribution of information resources about scientific researches requires analysis of recent researches on physical culture and sports problems in students' medium. It will permit to mark out promising directions of these topics' development.

\section{Purpose, tasks of the work, material and methods}

The purpose of the work is analysis of researches on physical culture problems among students in countries of Easter-European region (2013-2015).

As sources of information we chose data base of Russia, Poland and Ukraine. Besides, we used sites of the most known journals of Easter-European region.

\section{Results of the researches}

The most interesting for analysis was journal "Physical education of students" (http://www.sportedu.org.ua), which is in the data base of Russia (RISC), Poland (Index Copernicus) and Ukraine (bibliometryka of Ukrainian science) (see tables 1,2,3). This journal to the largest extent presents researches' results, devoted to problems of students'; physical culture and sports. The journal takes leading positions by citation. In rating Index Copernicus the journal goes just after publications, which have impact factor.

Table 1. Rating of journals in RISC data base (Physical culture and sports; 64 journals in total) for 2014 by indicator SCIENCE INDEX (http://elibrary.ru)

\begin{tabular}{llll}
\hline № & \multicolumn{1}{c}{ Name of journal } & Indicator \\
\hline 1. & Equine and horse riding & 0,195 & \\
2. Sports; economic, law, management & 0,178 & \\
3. Theory and Practice of Physical Culture & 0,177 & \\
4. Bulletin of sport science & 0,133 & \\
5. Physical culture: cultivation, education, training & 0,132 & \\
6. Physical Education of Students & $\mathbf{0 , 1 2 7}$ & \\
\hline
\end{tabular}

Table 2. Rating of journals in Index Copernicus data base (Sciences about sports; in total 27 journals were indexed; other have no indices) for 2013 by indicator ICV (http://www.indexcopernicus.com)

\begin{tabular}{rllll}
\hline №oo & Journal & ISNN & Country & ICV 2013 \\
\hline 1. & Archives of Budo & $1643-8698$ & Poland & 16.04 \\
2. & Biology of Sport & $0860-021 \mathrm{X}$ & Poland & 13.74 \\
3. & Physical Education of Students & $\mathbf{2 3 0 8 - 7 2 5 0}$ & Ukraine & $\mathbf{7 . 6 0}$ \\
\hline
\end{tabular}


Table 3. Rating of journals in data base "Bibliometryka of Ukrainian science" (TOP 200, all sciences) for 2010-2014 by indicator h5 (http://nbuviap.gov.ua)

\begin{tabular}{llc}
\hline Item number & Journal & Index h5 \\
\hline 10 & Theory and methodic of physical education & 14 \\
$\mathbf{1 4}$ & Physical Education of Students & $\mathbf{1 3}$ \\
23 & Pedagogics, psychology, medical-biological problems of physical training and sports & 11 \\
\hline
\end{tabular}

The researches for 2013-2015 are presented by Ukrainian authors (70\%) and by authors from other countries $(30 \%)$. Thematic focus of the researches is presented by articles about different aspects of physical education, sports, and students' health. Topics cover also adjacent areas: bio-mechanics, kinesiology, medicine, psychology, sociology, technology of sport equipment. Besides, topics include researches of effectiveness of trainings and sport selection, workability, health protection and other interdisciplinary directions (see fig. 1).

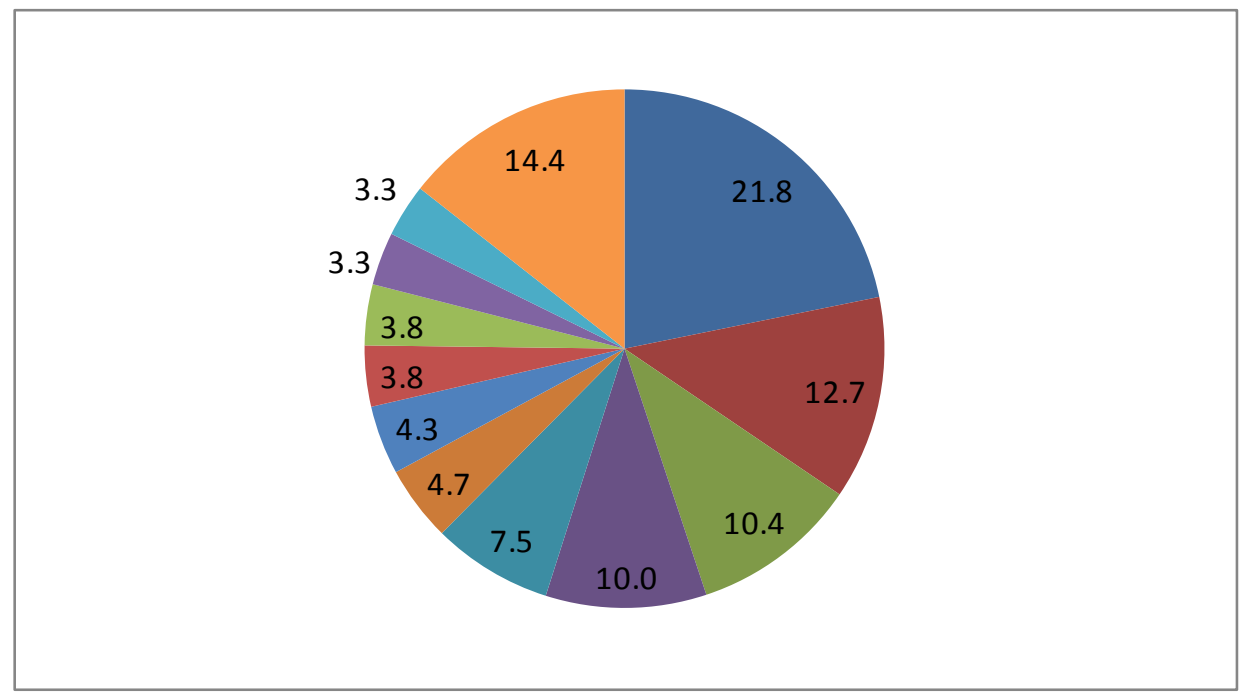

Fig.1. Topics of scientific researches of students' physical culture and sports problems, $\%$ : 1-Health and life quality, 21.8\%; 2-Physical education, 12.7\%; 3-Sport games, 10.4\%; 4-Martial arts, $10.0 \%$; 5Acrobatic, gymnastic, kinds of aerobics, 7.5\%; 6-Power kinds of sports, 4.7\%; 7-Biomechanics, 4.3\%; 8-Psychological problems, 3.8\%; 9-Water and winter kinds of sports, 3.8\%; 10-Cadets' training, 3.3\%; 11-Teachers' training, 3.3\%; 12-The rest, $14.4 \%$.

The highest quantity of researches is presented in direction "Health and life quality" $(21.8 \%)$. Authors determined general and specific components of health: motor functioning [111, 114, 123, 197-199, 207, 208]; motivation [57, 64, 68]; morphological-functional state [29]; psychological state [69, 91]; self-assessment [28, 99, 112, 163, 118-121, 135] and etc. The authors render specific recommendations on increasing of health and life quality indicators [52, 53, 56, 58].

Among above listed works there are works, characterizing modern students:

1) Absolute majority of students have resilience indicators high or within norm [140];

2) Dynamic of students' physical workability depends on period of student's studying in university. During all academic week physical condition changes are typical for first and second year students. Concerning third year students, the curve of dynamic workability has descending character. In senior students it has ascending descending character [156];

3) Alternation and equal correlation of motor elements and sport game elements increase general level of somatic health, cardio-vascular system's functional state, self-feeling, activity and emotional state of students [82];

4) Possibility of students' division into groups by indicators of functional shifts in extreme situations is shown. The most important indicators are quickness and accuracy of psycho-physiological tests passing with different modes of signal supply as well as functional shifts before fulfillment of exercise of extreme character [87].

Among other works we can mark out researches, oriented on increasing of life quality indicators [158, 165-170, 172].

The promising direction of further researches in this direction we can consider the works, which pay attention to the following:

-Changes in social-economic way of students' life [148];

- Re-organization of students' physical education system;

- Interconnection of life quality and organism's resistance to external impacts [123]; 
- Interconnection of parameters of subjective life quality assessment and the factors of its formation depending on specialization; revelation of negative tendencies to reduction of students' life quality; dependence between motor functioning, positive attitude to own life quality and presence of bad habits, irrational eating, psychic overloads on students' organism [90];

- Application of new, attractive forms of physical functioning: sailing [160], rock-climbing [85, 164], hiking [34, 194]; cheer dance [155], cheer leading [108, 117], shaping [179], aerobic [15, 28, 186, 188], aqua fitness [139], sport and ballroom dances [134, 183]; some kinds of sport martial arts [13, 72, 111, 201].

In general structure of the researches "Physical education" took $12.7 \%$.

Authors give recommendations on the following problems of students' physical education:

1) Motor functioning directly influences on students' educational progress and morbidity. Original technology of regulation of students' motor functioning on the base of control over their independent physical trainings is offered. It is recommended to practice independent training for not less than 15 minutes a day (in the morning, day and in the evening) with periodicity of not less than 3-4 times a week [55];

2) Motivation for physical culture practicing results from different demands: demand in motion, demand in fulfillment of student's obligations, demand in competition functioning. It is offered to use game and competition methods: setting of certain, feasible for a student, training tasks; usage of sufficient number of sport equipment of proper quality; urge of students to independent physical exercises through system if encouragement [39];

3) It is offered to use a system of specific forms of trainings' organization, which would meet humanistic principle "to urge but not to force". The function of such methods shall imply reconstruction of students' motivational sphere and adequately accepted by them purpose of functioning [78];

4) It was found that specially organized elective trainings on three disciplines (Pedagogic anthropology, Personality-oriented physical education, Creative valueology) formed sufficient volume of knowledge in undergraduate students. Some problems of innovative technologies' application in students' theoretical and practical trainings were outlined [17-19];

Among other researches we can note the following works: training of power abilities [171], pedagogic control of students' physical condition [11, 12], formation of personalities' physical culture of students [16, 131], individualization of physical education process [14], optimization of physical education [76, 77, 124-126, 129, 136], sport-oriented physical education $[35,133]$.

The promising direction of further researches in this direction we can consider the works, which pay attention to the following:

- Changes of students', having bad habits, functional indicators [141];

- Regulation of students' motor functioning, considering motivation for success and avoiding failures [49];

- Personality-oriented approach [18].

Direction of trainings "Sport games" took $10.4 \%$ in total structure of the researches.

Authors give recommendations on increasing of students' sportsmanship: basketball [27, 86, 150, 176, 180, 181]; baseball [6]; volleyball [36, 210]; handball [47]; tennis [43, 65, 83, 173]; football [1, 20, 59, 113, 200]; hockey [89]. The authors accentuate attention on consideration of peculiarities of different sides of students-sportsmen's training, considering specificities of educational environment in educational establishment, specific features of students' competitions (Universiades, students' leagues on kinds of sport games).

The authors render the following recommendations on students' sport games:

1) Analysis of basketball throws' accuracy, basketball players' logical thinking and depth of perception. It was found that ability to think logically and certain depth of perception were two main variables. These variables influence on deviations in basketball players' throw accuracy [176].

2) It was shown that the offered simulation methods permit to form optimal orientation of training process with application of specialized means at different stages of year cycle of volleyball players' training [36].

3) Analysis of different qualification female handball players' selection through interconnection of psycho-physical parameters showed that elite sportswomen are characterized by average and high degree of dependence of competition functioning successfulness on space perception indicators, on logical and space thinking [47].

4) The researches permitted to find the following correlation of rugby players' special physical training: September - special endurance is accentuated (100\% of training time); October - special endurance (70\%), power endurance (20\%), training of strength (10\%); November - accordingly 50, 30, 20\%; December - 30, 40, 30\% [137].

The promising direction of further researches in this direction we can consider the works, which pay attention to the following:

- Inviting of sportsmen to educational establishments;

- Mechanisms of educational establishment's interest in development of students' sports;

- Creation of conditions for combination of academic studies with trainings of sportsmen;

- Determination of factors, facilitating motivation for sport games in system of students' health related trainings

[59]. 
Among other researches we can note the works, devoted to practicing of sport games by disabled students [180]. It should be added with researches of problems of women football teams' training [60], students' involvement in refereeing of sport games' competitions [20,113].

Direction "Martial arts took $10 \%$ in total structure of the researches.

The authors render the following recommendations on improvement of students' sportsmanship in the following kinds of martial arts: arm wrestling [142-146, 204], boxing [7, 73, 74, 114, 115], freestyle wrestling [25], Greco-Roman wrestling [195], Judo [66], Kick boxing [177], Thae quan do [67, 132], fencing [26, 105], other kinds [95-97].

The authors note that it is necessary to attract students to different kinds of martial arts and underline health related significance of sport martial arts.

Among the most interesting researches we would like to mark out solution of the following problems:

1) Working out of system of sportsmen's training individualization. In this case system is simulated as combination of elements and subsystems, which mutually, in controlled way, facilitate revelation, formation, development and perfection of personal martial art style [98].

2) It was found that hand dynamometry is an important and informative criterion, which determines arm wrestling training. Such criterion is characterized by maximal system-formation contribution [114].

3) It was shown that increase of sportsmanship reflects in rising of blows' density in duel. Innovations in competitions rules resulted in high intensity of combat actions in boxing. Attacking actions are fulfilled with rater higher quickness [115].

4) It was found that final part of competitions is the most informative for assessment of wrestlers' technical tactic abilities. It is determined by efficiency, effectiveness, quantity of attacks, technical arsenal. It was shown that wrestlers shall conduct duel at rapid rate. It is recommended to use movements, pulls, pushes as well as to make 1-2 actual attempts to fulfill definite technique [196].

The promising direction of further researches in this direction we can consider the works, which pay attention to the following:

1) Substantiation of approaches to development of future specialists' assertiveness by martial arts' means (sambo and judo). Means of sport martial arts are described as tools of personality's qualities training in future specialists. Potentials of assertiveness formation by martial arts' means are determined [72].

2) Analysis of different aspects of students' resistance to psycho-physiological stresses at martial arts trainings is presented. Specificity of individual psychologically-oriented methodology in modern system of martial arts is elucidated as well as its usage at physical education trainings. It is noted that the most destructive factors are excessive psychogenic stresses, caused by unfavorable psychological factors. Psychogenic stress influence in the most destructive way on health. It is the main reason of students' morbidity. Authors recommend didactically literally worked out methodic of prophylaxis [201].

3) Authors give analysis of cadets' endurance and workability rising by means of martial arts. As exercises for special endurance they recommend: throws of partner with high intensity; throws in average temp; training duels $[8,9]$.

“Acrobatic, gymnastic, different kinds of aerobics" took 7.5\% [10, 84, 109, 110].

The authors give recommendations on the following problems:

1) Influence of health related aerobics on girls' motor fitness [175].

2) Dozing of physical loads at girl students' aerobic trainings [15].

3) Assessment of pedagogical HEEs girl students' communicative skills resulted from aerobic trainings [188].

4) Application of highly intensive training means at health related aerobic trainings [28].

5) Training of girl students' physical condition at extra curriculum cheer dance sessions [155].

6) Development of pedagogic college girl students' quickness and endurance under influence of cheer leading [117].

7) Interconnection of general and special physical fitness indicators of students cheer leaders at stage of specialized basic training [108].

The authors note high motivation of girls for health related trainings with dance exercises. Such authors' position is a perspective direction of organization of girl students' different motor functioning kinds.

Other researches are presented in the following directions:

1) Power kinds of sports (4.7\%) [42, 102, 153, 154, 178, 185, 202, 203, 209];

2) Bio-mechanics (4.3\%) [127, 128];

3) Psychological problems (3.8\%) $[21,45,46]$;

4) Water and winter kinds of sports (3.8\%) [174];

5) Training of cadets $(3.3 \%)[33,44,94]$;

6) Training of teacher $(3.3 \%)[62,63,187]$;

7) Other researches $(14.4 \%)[22,24,70,71,104,106,107,116,192,193]$; 
Among them researchers, devoted to protection and strengthening of students' health [29-32, 37, 48, 75, 122], and training of physical condition [79-81, 92, 93, 184, 205] can be marked out.

The promising directions in this case can be solution of the following problems with the help of modern means of health bio mechanical indicators' registration:

1) It was found that $63,3 \%$ with normal posture were in risk zone. Students with worsened posture's bio-geometric profile (scoliosis posture - 43,33\%; round back- 23,33\%; slouching back- 22, $73 \%$ ) got in the so-called premorbid state of muscular skeletal apparatus [38].

2) Quantitative indicators of bio-dynamic and coordination structure of motor qualities during aerobic training are determined. Bio-mechanical models are offered for control of motor fitness and prognostication of results [186].

3) It was found that there is objective demand in studying of bio-mechanical characteristics of free style wrestlers' technique. Such approach is required for further development of technology of athletes' sport technique formation at stage of initial basic training [206].

Ensuring of disabled students' life quality shall be considered to be promising direction of researches:

1) The researches proved that practicing of sports by disabled persons influence positively on their life quality. Research of aspect of life quality perception is a complex problem, but it deserves proper attention and appropriate efforts $[23,138]$.

2) Also organizational-methodic priorities of disabled students' physical education and sports were revealed. Application of physical education model permits their complete integration in students' medium. Students feel themselves more comfortable. They change their attitude to themselves. It is reflected in adequate perception, in finding certain masking of disability, in self presentation. The authors showed effectiveness of didactic technology of disabled students' physical education in pedagogic process [5].

Training of future teachers is not less important as well as their physical condition. In this aspect we can mark out the following problems:

1) Formation of future teacher's culture of health [61];

2) Emotional competence of future physical culture teachers [161];

3) Methodological requirements of competence approach in hiking education of future teachers [40, 41];

4) Competence and professional skillfulness of specialists in physical culture [182].

\section{Discussion}

Analysis of publications on problems of physical culture and sports in students' medium shows that most of scientists' recommendations remain out of higher educational teachers' and coaches' attention. There can be several reasons to this fact:

1) Level and quality of trainings of teachers themselves as well as their unwillingness to use modern technologies of students' health improvement in their practice.

2) Students' low motivation for physical culture and sports practicing in their every day life.

3) Insufficient material-technical provisioning of training sites as well as insufficient financing of physical culture and sports.

4) Students' overloading in week academic program. Transition from 36 hours' week to 30 hours' did not influence noticeably on students' activity.

5) Changes in higher educational establishments' curriculums, in which discipline "Physical culture" became an optional one.

The situation can be changed by proper organization of students' military patriotic education, application of more attractive physical functioning forms, usage of motivation approaches, implementation of encouragement and rating system in functioning of teachers and student.

It should be noted that it is necessary to use the above mentioned promising researches in scientific work of higher educational establishments. All these, taken together, will facilitate formation of teachers' positive attitude to their works and students' - to their health.

\section{Conclusions}

We can relate the following works to possible promising in the future researches:

1) Re-organization of students' physical education system.

2) New attractive forms of students' physical functioning.

3) Regulation of students' physical functioning, considering motivation for success and avoiding failures.

4) Inviting of students-sportsmen in educational establishments.

5) Mechanisms of educational establishments' interest in development of students' sports.

6) Creation of conditions for combination of academic classes with sport trainings for sportsmen.

7) Determination of factors, facilitating increasing of motivation for sport games in system of students' health related trainings.

8) Strengthening of students' resistance to psycho-physiological stresses.

9) Perception of life quality by disabled students. 
10) Formation of student's culture of health.

11) Competence and professionalism of specialists in sphere of physical culture and sports.

\section{Conflict of interests}

The authors declare that there is no conflict of interests.

\section{References:}

1. Abdula AB, Lebedev SI. Features of physiological responses on organism of football players aged 10-12 years in exercise using different training methods. Physical education of students, 2014;1:3-8.

2. Adashevskiy VM, Iermakov SS, Firsova IuIu. Physical mathematical modelling of difficult elements of acrobatic rock-and-roll. Physical education of students, 2013;3:3-11.

3. Adashevskiy VM, Iermakov SS, Korzh NV, Muszkieta Radoslaw, Prusik Krzysztof, Cieslicka Miroslawa. Biomechanical study athletes' movement techniques in the hurdles (on example of phase of flight). Physical education of students, 2014;4:3-12.

4. Adashevskiy VM, Iermakov SS, Marchenko AA. Biomechanics aspects of technique of high jump. Physical education of students, 2013;2:11-18.

5. Adyrkhaev SG. Optimization of physical education and sports of students with disabilities throughout the entire period of study at the university. Physical education of students, 2013;6:3-8.

6. Agapov DV, Krovykov VF, Boyko UG, Hodorchenko VM. Method of estimation of technical preparedness level of baseballs aged 12-14 years. Physical education of students, 2013;2:3-11.

7. Aksutin VV, Korobeynikov GV. Study of special capacity in boxers with different styles of fight. Physical education of students, 2014;5:3-7. http://dx.doi.org/10.15561/20755279.2014.0501

8. Alekseev NA, Kutergin NB, Kulinichev AN, Gorbatenko AV. Integrated method development of general and special students stamina involved in the fight. Physical education of students, 2014;3:3-9.

9. Alekseev NA, Kutergin NB, Kulinichev AN. Perfection of physical training of students and listeners of educational establishments of Ministry of Internal Affairs of Russia. Physical education of students, 2013;1:3-7.

10. Bachinskaya NV. Features of construction of structures in long-term training acrobatics at the modern stage. Physical education of students, 2015;1:3-10. http://dx.doi.org/10.15561/20755279.2015.0101

11. Balamutova NM, Shyryaeva SV . Study of special performance and volume training loadings at swimmers in the year preparation. Physical education of students, 2014;1:8-13.

12. Balamutova NM. Pedagogical control of students' physical state after research results of cardiovascular system functional indicators. Physical education of students, 2013;1:7-12.

13. Baljinder Singh Bal. Impact of short-term Bhastrika Pranayama on respiratory parameters: an ancient practice with contemporary significance. Physical education of students, 2015;3:66-73. http://dx.doi.org/10.15561/20755279.2015.0308

14. Barybina LN, Kolomiec NA, Komotskaja VA. The application of the algorithm of the individualization of students' physical education process. Physical education of students, 2014;6:3-7. http://dx.doi.org/10.15561/20755279.2014.0601

15. Beliak YuI, Zinchenko NM. Dosing method of physical activity in aerobics classes for students. Physical education of students, 2014;5:8-13. http://dx.doi.org/10.15561/20755279.2014.0502

16. Belykh SI, Chernigovskaia SA. About forming of personality physical culture of students in the process of physical education (in aspect of athletic activity). Physical education of students, 2013;2:18-25.

17. Belykh SI. Estimation of efficiency of experimental model of optimization of teaching of students of faculty of physical education. Physical education of students, 2013;5:3-13.

18. Belykh SI. Methodological foundations of individually oriented approaches to ground of physical education unprofessional university students. Physical education of students, 2013;3:11-18.

19. Belykh SI. Structure of the concept of personality oriented physical education university students. Physical education of students, 2013;4:3-10.

20. Berezka SM, Chopilko TG. An investigation of individual functionality football referees qualifications. Physical education of students, 2014;6:8-12. http://dx.doi.org/10.15561/20755279.2014.0602

21. Bilichenko EA. Gender aspects of personal and motivational sphere of students to physical education and sport. Physical education of students, 2013;6:8-15.

22. Bobrovnik VI, Tykhonenko YP. Improvement of strength capacities of middle-distance runners as the major factor of achieving high sports results at the stage of maximal realization of individual capabilities. Physical education of students, 2014;3:9-18.

23. Bolach Bartosz, Prystupa Tetyana. Evaluation of perception of quality of life of disabled athletes. Physical education of students, 2014;1:13-17.

24. Bondar TS. Classification of physical education of adolescent by subjects of pedagogical influence. Physical education of students, 2013;3:18-22. 
25. Boyko VF, Malinsky II, Andriitsev VA, Yaremenko VV. Competitive activity of highly skilled freestyle wrestlers at the present stage. Physical education of students, 2014;4:13-19.

26. Briskin YA, Pityn MP, Zadorozhnaya OR. Structure and content of fencers' theoretical training. Physical education of students, 2013;4:10-15.

27. Brynzak SS, Krasnov VP . Role of force training in physical training of student basketball team players. Physical education of students, 2013;5:13-18.

28. Bryukhanova NA, Bulgakova OV, Mokrova TI, Bogashchenko YA. Determination of possibilities of the use of highintensive trainings facilities on lessons health aerobics. Physical education of students, 2013;2:25-30.

29. Bukov UA, Georgieva NG. The ways of teaching process optimization in physical education of the students' special medical group. Physical education of students, 2013;3:22-26.

30. Cherednychenko MA, Artemieva GP. Special physical preparation of athletes in motor sport during testing methods basic training level of preparedness for competitive athlete load. Physical education of students, 2014;2:46-50.

31. Chernenko S A. Description of how the specialization influences the dynamics of the functional and motor abilities among the third to fifth year male student. Physical education of students, 2014;1:50-56.

32. Chovgan RYa, Ivanishyn IM, Prezliata AV. Level of development of the physical components of social activity schoolchildren 10-11 years children summer camp. Physical education of students, 2014;2:50-56.

33. Danylchenko VA, Khabinets TA. Typical mistakes, made by the cadets, mastering the submission locks, of the higher educational establishments of the Ministry of Internal Affairs of Ukraine. Physical education of students, 2014;4:20 25.

34. Denisenko IA. The peculiarities of functional state changes of cardiovascular system of girls at the age 18-19 years in the process of practicing sport and health tourism. Physical education of students, 2013;5:32-37.

35. Dolinnyj UA, Olejnik ON, Sorokin US, Homenko AA. Physical education of students from sports-oriented technologies. Physical education of students, 2013;5:37-41.

36. Doroshenko EIu. Model parameters of technical and tactical actions in the competitive activities of volleyball players. Physical education of students, 2013;5:41-46.

37. Drogomeretsky VV, Kondakov VL, Gorelov AA. Application of improving swimming to the correction of joint and ligament students. Physical education of students, 2013;5:46-55.

38. Dudko MV. Characteristic of bio-geometric profile of students' posture and physical fitness in process of physical education. Physical education of students, 2015;4:10-16. http://dx.doi.org/10.15561/20755279.2015.0402

39. Dudnyk IO. Formation of positive motivation as the basis of students will qualities' perfection in physical culture practicing. Physical education of students, 2015;3:3-9. http://dx.doi.org/10.15561/20755279.2015.0301

40. Dudorova LJ. Conceptual approaches to vocational and tourism training of teachers in higher education institutions. Physical education of students, 2013;4:19-23.

41. Dudorova LJ. Methodological requirements of the competitive approach in tourist formation of the future teachers. Physical education of students, 2014;2:13-18.

42. Dzhym VYu. Peculiarities of perfection of training process of the qualified bodybuilder in the competitive period.. Physical education of students, 2015;1:11-16. http://dx.doi.org/10.15561/20755279.2015.0102

43. Emshanova YO. Comparative analysis of individual peculiarities for tennis players of different qualification. Physical education of students, 2013;4:23-27.

44. Evtushov FM. Features of organization and extra-curricular classes on the subject "Special physical education" with the cadets of higher educational establishments of Ministry of Internal Affairs of Ukraine. Physical education of students, 2013;1:27-30.

45. Fatemeh Eloon Kashkuli, Mehrdad Moharramzadeh, Sohrab Ghalehgir. The role of advertisement factors in development of sport tourism industry of fars province . Physical education of students, 2014;3:61-67.

46. Feuerman VV. Influence of socio-philosophical and spiritual values on the formation of social orientation and physical health specialists the sphere of physical culture and sports. Physical education of students, 2014;2:41-46.

47. Frolova LS, Glazirin ID, Petrenko YO, Suprunovich VO, Menshikh EE, Kharchenko IA, Pivnenko AO. Effect of psychophysical state on different qualification's handball players on their preparedness. Physical education of students, 2013;3:72-75.

48. Futornyi SM. Problem of shortage of motor activity students. Physical education of students, 2013;3:75-80.

49. Gavrishova EV, Gorelov AA. On the regulation of motor activity of students with the motivation to achieve success and avoid failure. Physical education of students, 2013;5:18-25.

50. Gerasevich AN, Shytov LA, Shytova EM, Bokovets VS, Schenovsky YI, Gmir TA, Parkhots EG. Comparative characteristics of the separate morphological and functional state indicators of the organism of modern students (Part 1). Physical education of students, 2013;5:25-32.

51. Goginava SE, Rumba OG. On improving effect combining aerobic and anaerobic loads of character in the classroom for physical training in universities. Physical education of students, 2014;3:18-30. 
52. Gordieieva MV. Perfection of hoe-type motions of sportswomen specialized in synchronous swimming in base positions of compulsory exercise. Physical education of students, 2013;2:30-35.

53. Gordienko YV. Theoretical training in physical education of higher educational establishments' girl students. Physical education of students, 2015;4:3-9. http://dx.doi.org/10.15561/20755279.2015.0401

54. Gorelov AA, Kondakov VL, Belikova ZhA. About necessity of use of Hatha Yoga exercises for correction of deformation of students' spine of special medical groups with violations of posture. Physical education of students, $2013 ; 2: 35-45$.

55. Gorelov AA, Kondakov VL, Usatov AN. To the question about the use of independent physical training in educational space of modern higher institute. Physical education of students, 2013;1:17-27.

56. Grad Rafal. Physical activity and leisure time among 13-15-year-old teenagers living in Biala Podlaska. Physical education of students, 2013;2:74-80.

57. Grygus IM, Kucher TV. Optimizing the level of the physical health of the students with a glance of the type of autonomic nervous system. Physical education of students, 2013;3:26-31.

58. Hamid Mohebbi, Abdulbaset Maroofi, Nazanin Anasri, Aboozar Jorbonian. The effects of stretching exercise on hemodynamic responses and post-exercise hypotension in normotensive women students. Physical education of students, 2014;5:53-58. http://dx.doi.org/10.15561/20755279.2014.0510

59. Hotenceva EV, Shpichka TA. The motivation for playing football among students. Physical education of students, 2013;3:80-84.

60. Huzar VN, Shalar OG, Norik AO. Relationship as an aspect of psychological climate of women's soccer team. Physical education of students, 2014;2:8-13.

61. Iermakova TS. Forming a health culture of future teachers in Polish educational establishments. Physical education of students, 2014;5:14-19. http://dx.doi.org/10.15561/20755279.2014.0503

62. Ilnitskaya AS, Kozina ZhL, Barybina LN, Kolomiez NA, Cieslicka Miroslawa, Stankiewicz Blazej, Pilewska Wieslawa. Author's internet blog as information and communication technologies in the educational space within the physical education students. Physical education of students, 2014;1:22-27.

63. Ilnitskaya AS, Kozina ZhL, Lakhno E G, Ilnitskaya LV, Cieslicka, Miroslawa, Stankiewicz Blazej, Pilewska Wieslawa. Students' attitude to the possibility of applying modern information and communication technologies in the educational process in physical education. Physical education of students, 2014;2:18-25.

64. Ivaskiene VP, Skyriene VV, Markevicius VZ. Comparative analysis of prestart condition of students girls in Olympic and non-Olympic kinds of sport. Physical education of students, 2013;4:27-31.

65. Jagiello M, Jagiello W. Final preparations to the girls' tennis Europe junior masters. Physical education of students, 2014;5:59-64. http://dx.doi.org/10.15561/20755279.2014.0511

66. Jagiello Wladyslaw, Dornowski Marcin, Wolska Beata. Basic technical skills (throws) in 17-19-year-old judokas. Physical education of students, 2014;6:77-80. http://dx.doi.org/10.15561/20755279.2014.0615

67. Jagiello Wladyslaw, Kozina ZhL, Jagiello Marina. Somatic aspects of sports championship in taekwon-do ITF. Physical education of students, 2015;4:51-55. http://dx.doi.org/10.15561/20755279.2015.0408

68. Kazem Sotoode, Bahman Mirzaei, Farhad Rahmani-Nia. Influence of upper-body exercise order on muscle damage in untrained men. Physical education of students, 2013;5:100-108.

69. Kazem Sotoodeh, Aliakbar Alizadeh, Bahman Mirzaei. The comparison of three type of exercise sequence on maximum strength in untrained young men. Physical education of students, 2014;5:65-69. http://dx.doi.org/10.15561/20755279.2014.0512

70. Kedrovskiy BG, Shalar OG, Grinevich AV. Understanding of coaches with young athletes. Physical education of students, 2013;4:31-35.

71. Kholodova OS. Modeling of competitive activity of skilled athletes specialized at $1500 \mathrm{~m}$ distance on short-track skating. Physical education of students, 2013;5:93-100.

72. Khripunova LD. To the question of the formation of personal qualities of future doctors by means of combat sports. Physical education of students, 2014;5:43-47. http://dx.doi.org/10.15561/20755279.2014.0508

73. Kiprych SV, Donets AV, Makhdi Omar Ali. Improvement of management by training process of boxers at a stage of direct preparation for competitions. Physical education of students, 2013;6:20-25.

74. Kiprych SV. Control system improvement of qualified boxers based assessment system change reaction cardiorespiratory during the immediate preparation for competition. Physical education of students, 2014;4:26-31.

75. Klimatskaya L G. Physical activity students and university professors as leaders of health. Physical education of students, 2013;3:31-35.

76. Kolokoltsev MM, Ambartsumyan RA. Improving physical health international students enrolled in a technical college in Baikal region. Physical education of students, 2014;1:34-39.

77. Kolokoltsev MM, Cieslicka Miroslawa, Muszkieta Radoslaw. Optimization of physical training of students of high school with regard to quantitative features muscular components of their bodies. Physical education of students, 2015;1:17-21. http://dx.doi.org/10.15561/20755279.2015.0103 
78. Kondakov VL, Kopeikina EN, Balysheva NV, Usatov AN, Skrug DA. Causes of declining interest of students to employment physical education and sports. Physical education of students, 2015;1:22-30. http://dx.doi.org/10.15561/20755279.2015.0104

79. Konovalov VV, Kirpenko VN, Marakushyn AI, Poddubny AG. Grounds of optimum level of development of basic physical qualities which provide high level the functional state of students in the period of flying training. Physical education of students, 2013;5:55-60.

80. Korobeynikov GV, Drojjin VU. The prevention programs of physical rehabilitation for chernobyl disaster survivors. Physical education of students, 2013;1:78-82.

81. Kovalenko SO, Nechyporenko DL. Application of biological feedback for estimation of anaerobic performance in jumping test. Physical education of students, 2014;5:20-24. http://dx.doi.org/10.15561/20755279.2014.0504

82. Kovaleva MV, Rumba OG. Active games in physical education students of special medical group with limited capacity of cardiovascular system. Physical education of students, 2013;4:35-46.

83. Kozak A M, Ibraimova M V. Construction of training process of tennis players aged 5-6 years, taking into account the specifics of the development and control of their coordination skills. Physical education of students, 2014;6:1723. http://dx.doi.org/10.15561/20755279.2014.0604

84. Kozhanova OS. Compatibility of sportswomen at selection in commands on group exercises of artistic gymnastics accounting their functional condition. Physical education of students, 2013;1:33-37.

85. Kozina Zh, Ryepko OA, Prusik Krzysztof, Prusik Katarzyna, Cieslicka Miroslawa. Theoretical-methodological study of development of power-speed in climbing. Physical education of students, 2014;1:27-34.

86. Kozina ZhL, Sobko IN, Prokopenko AI, Guba AV, Iermakov SS, Prusik Krzysztof, Cieslicka Miroslawa. Methods of technical and tactical training basketball players with hearing impairments using innovative technologies. Physical education of students, 2014;3:30-40.

87. Kozina ZL, Iermakov SS. Analysis of students' nervous system's typological properties, in aspect of response to extreme situation, with the help of multi-dimensional analysis. Physical education of students, 2015;3:10-19. http://dx.doi.org/10.15561/20755279.2015.0302

88. Kramida I E. Exercises for students of different medical groups as factors of the weakening bad habits at students. Physical education of students, 2013;4:46-51.

89. Kugayevskiy SO. Innovative ways of special endurance of skaters in the competition period. Physical education of students, 2013;4:51-55.

90. Kulthickiy ZI, Kurko YaV. Analysis of the main parameters of quality of students' life of different specialties. Physical education of students, 2013;6:25-30.

91. Kurmaeva EV. Fitness - programs as mean of forming of personality physical culture of students. Physical education of students, 2013;1:37-40.

92. Kutek TB. Application of hardwares in the process of training of skilled sportswomen. Physical education of students, 2013;5:60-65.

93. Kutek TB. Features special physical readiness of the qualified jumpers from the takeoff. Physical education of students, 2015;2:3-7. http://dx.doi.org/10.15561/20755279.2015.0201

94. Kutergin NB, Tkachenko AI, Kulinichev AN. Physical perfection of students of educational institutions law enforcement by means of outdoor games. Physical education of students, 2013;6:30-34.

95. Latyshev SV, Korobeynikov GV. Approach of the systems to problem of individualization of training of fighters. Physical education of students, 2013;5:65-69.

96. Latyshev SV. Individualization program training in freestyle wrestling. Physical education of students, 2013;6:3438.

97. Latyshev SV. The development of assessment scales of physical training of wrestlers at the stage of basic specialized training. Physical education of students, 2013;4:55-59.

98. Latyshev SV. Theoretical bases of individualization of training in wrestling. Physical education of students, $2013 ; 2: 45-49$.

99. Lazarenko MG. Pedagogical aspects of effective use of simulator "Straps with ring" during the formation motor skills of pupils of 10 classes during the skiing training in the lessons of physical culture. Physical education of students, 2014;6:24-28. http://dx.doi.org/10.15561/20755279.2014.0605

100.Leyfa AV. The social basis of the development of physical activity of students in terms of their quality of life. Physical education of students, 2013;3:35-42.

101.Lisowski VO, Mihuta IYu. Importance of coordination skills essential psychophysical demonstrated competencies as a military specialists. Physical education of students, 2013;6:38-43.

102.Litvinenko AM. Efficiency of application of means of sports preparation of combat sportsmen in physical training of students of technical high school. Physical education of students, 2013;2:49-54. 
103.Litvinenko YV, Niznikowski Tomasz, Boloban VN. Evaluation of the kinematic structure of indicators key elements of sports equipment exercise by postural orientation movements. Physical education of students, 2014;6:29-36. http://dx.doi.org/10.15561/20755279.2014.0606

104.Liu Yong Qiang. Operative correction of judoists' training loads on the base of on-line monitoring of heart beats rate. Physical education of students, 2015;2:13-21. http://dx.doi.org/10.15561/20755279.2015.0203

105.Lopatenko GO, Tumanova VN, Gatsko EV. Application of mobilizing extra-training means in process of pre-start martial arts sportsmen's training (on example of fencing). Physical education of students, 2015;2:8-12. http://dx.doi.org/10.15561/20755279.2015.0202

106.Lotfali Bolboli, Navid Lotfi, Mostafa Bagheri, Ali Rajabi. Evaluation and comparison of VO2max assessment models in high school students. Physical education of students, 2013;2:80-83.

107.Lutovinov IuA, Martin VD, Oleshko VG, Lisenko VN, Tkachenko KV. Physical development, the level of physical and technical preparedness of $14-15$ year old young weightlifters of different weight categories groups. Physical education of students, 2014;5:25-29. http://dx.doi.org/10.15561/20755279.2014.0505

108.Lutsenko LS, Bodrenkova IA. Correlation of general and special physical training of athletes cheerleaders at the stage the specialized training base. Physical education of students, 2013;6:43-50.

109. Lyulina NV, Zakharova LV, Vetrova IV. Effect of complex acrobatic elements in the development of physical skills of preschool children. Physical education of students, 2013;4:59-63.

110.Makarova OV. Quantitative estimation of the state of vault feet gymnasts on the different stages of the long-term training. Physical education of students, 2013;5:69-73.

111. Maksimuk OV, Vrublevskiy EP, Lin Wang. Students' motivation to study Chinese recreational gymnastics classes wushu. Physical education of students, 2014;3:40-44.

112. Malakhov VA, Puhach YaI, Serebrjakov AM, Bakanova AF, Druz VA. Influence of the emotional state on behavior in extreme conditions of competitive sports activities. Physical education of students, 2014;2:25-33.

113. Manilo YV. Locomotor activity of professional football referees. Physical education of students, 2014;6:37-40. http://dx.doi.org/10.15561/20755279.2014.0607

114. Martsiv VP. Comparative analysis of competitive activity parameters of amateur boxers high qualification. Physical education of students, 2014;6:41-44. http://dx.doi.org/10.15561/20755279.2014.0608

115. Martsiv VP. Model characteristics of average skill boxers' competition functioning. Physical education of students, 2015;4:17-23. http://dx.doi.org/10.15561/20755279.2015.0403

116. Martyniuk OV, Vilyanskiy VN. Assessment of students' health condition by indicators of adaptation potential, biological age and bio-energetic reserves of organism. Physical education of students, 2015;3:20-28. http://dx.doi.org/10.15561/20755279.2015.0303

117. Masliak IP. Quickness and endurance fitness of pedagogic college girl students under influence of cheer-leading. Physical education of students, 2015;4:24-30. http://dx.doi.org/10.15561/20755279.2015.0404

118. Mehran Azarian, Robab Yadollahzadeh, Mehrdad Hefzollesan, Mehrdad Moharramzadeh, Sohrab Ghalehgir. Order in the chaos in sports organizations. Physical education of students, 2014;4:49-54.

119. Mehrdad Hefzollesan, Sohrab Ghalegir. Study of postural abnormalities of male students of Sahand University of Technology. Physical education of students, 2013;2:83-87.

120.Mehrdad Hefzollesan, Sohrab Ghalehgir, Mostafa Ekrami. The effect of 36 hours sleep deprivation on dribbling skills of soccer players. Physical education of students, 2013;4:97-101.

121. Mehrzad Shabani, Saeid Shakerian, Rouholah Fatemi. Study of body mass index (BMI), body fat percent (\%BF), and waist to hip ratio (WHR) in male physical education students. Physical education of students, 2015;3:74-78. http://dx.doi.org/10.15561/20755279.2015.0309

122. Menshikh EE. The peculiarities of physical development of pupils and students. Physical education of students, 2013;6:50-55.

123. Michael Chia, Marcus Lee. Relationship between quality of life and resilience among sport-active Singaporean youth. Physical education of students, 2015;2:29-36. http://dx.doi.org/10.15561/20755279.2015.0205

124. Michuda YP, Zhuliaiev VN. Features of financing of mass sports in Europe at the beginning of XXI century. Physical education of students, 2013;1:40-45.

125. Mikhnov AP. Rationale set of indicators and prioritize relevant to assess competitive activity of hockey players of high qualification of different roles. Physical education of students, 2015;1:31-35. http://dx.doi.org/10.15561/20755279.2015.0105

126. Mukhamediarov NN. The theoretical basis of formation mental health of students on physical education. Physical education of students, 2013;3:42-46.

127. Muntian VS. Definition of biomechanical parameters of technical actions in the martial arts. Physical education of students, 2013;4:63-68.

128. Muntian VS. Theory of safety needs (about the theory of arise of physical education). Physical education of students, 2014;6:45-48. http://dx.doi.org/10.15561/20755279.2014.0609 
129. Mysiv V M. Physical readiness and performance of adolescents of different somatotype. Physical education of students, 2014;2:33-37.

130.Niewiadomska Monika. Agility as a modern form of recreation. Physical education of students, 2013;3:84-87.

131.Nooshing Benar, Ayoub Behrozi, Manizheh Mansor Sadeghi, Mahdi Mohammadi, Maryam Yosefi. The consideration of attitude and motives relative to leisure time activities in students of Guilan University, Iran. Physical education of students, 2013;4:101-107.

132. Ohromiy G V, Makarova NU, Kasyuha AM. Psychophysiological methods and criteria for the selection of individual metered loads in athletes of taekwondo section. Physical education of students, 2014;6:54-62. http://dx.doi.org/10.15561/20755279.2014.0611

133. Olkhovy OM, Petrenko YM, Temchenko VA, Timchenko AN. Model of students' sport-oriented physical education with application of information technologies. Physical education of students, 2015;3:29-37. http://dx.doi.org/10.15561/20755279.2015.0304

134. Omelyanenko VI. Complex integrated method of improvement of sports ballroom dance performance. Physical education of students, 2014;6:49-53. http://dx.doi.org/10.15561/20755279.2014.0610

135. Omelyanenko VI. Express-method of sportsmen's psychological tune-up. Physical education of students, 2014;3:4449.

136.Pashkevich LP. A structure of morbidity and prevalence of illnesses of the respiratory system in Ukraine. Physical education of students, 2013;4:68-72.

137.Pasko VV. Perfection of educational-training process on the basis of account of parameters special physical preparedness of rugby-players. Physical education of students, 2014;3:49-56.

138. Perederiy AV. The structure of the ensuring of the functioning of Special Olympics' program. Physical education of students, 2013;5:73-79.

139.Petrenko N V, Loza T A. Model of recreational and training sessions based on the use of funds aqua professionally applied in the preparation of students of economics. Physical education of students, 2014;4:32-36.

140.Pichurin VV. Resilience of students and their readiness for professional functioning. Physical education of students, 2015;3:38-43. http://dx.doi.org/10.15561/20755279.2015.0305

141.Pidpomoga AY. Dynamic of functional indicators' changes of students having harmful habits (on example of smoking) under influence of organized motion functioning. Physical education of students, 2015;2:22-28. http://dx.doi.org/10.15561/20755279.2015.0204

142.Podrigalo L V, Galashko M N, Galashko N I. Study of specificities of arm wrestlers' psychological status in competition period. Physical education of students, 2015;3:44-51. http://dx.doi.org/10.15561/20755279.2015.0306

143. Podrigalo LV, Galashko MN, Galashko NI . Goniometric researches of armwrestling sportsmen. Physical education of students, 2013;1:45-49.

144.Podrigalo LV, Galashko MN, Galashko NI, Prusik Krzysztof, Cieslicka, Miroslawa. Research of hands' strength and endurance indications of arm sport athletes having different levels of skills. Physical education of students, 2014;2:37-41.

145.Podrigalo LV, Galashko MN, Galashko NI. Study and evaluation of indicators of relationships motor analyzer sportsmen of armsport. Physical education of students, 2013;3:46-50.

146. Podrigalo LV, Platonova AG, Cieslicka M. Comparative analysis of vitamin status of schoolchildren in recreational period. Physical education of students, 2013;5:79-83.

147.Podstawski Robert, Boryslawski Krzysztof. Influence of pe teachers' qualifications on the motor abilities of early school-age children. Physical education of students, 2014;1:56-64.

148.Podstawski Robert, Boryslawski Krzysztof, Urbanska-Gizinska Renata. Physical and motor development of the students enrolled at the University of Warmia \& Mazury in Olsztyn, Poland, in relation to their financial and urbanization status. Physical education of students, 2014;6:81-89. http://dx.doi.org/10.15561/20755279.2014.0616

149.Podstawski Robert, Omelan Aneta, Zapert Monika, Zurek Piotr. School and out-of-school physical activity of children in rural areas. Physical education of students, 2014;4:55-60.

150. Pomeschskova IP, Kycherenko AS, Yevtushenko IM. Analysis of the performance of the Ukrainian women's team at the European Basketball Championship 2012. Physical education of students, 2013;1:49-54.

151.Prosvirina LN, Kolokoltsev MM, Kolchanova MA, Cieslicka Miroslawa, Stankiewicz Blazej. The characteristic of the engine qualities of the students of technical institute of III functional health group (special medical group). Physical education of students, 2015;1:43-49. http://dx.doi.org/10.15561/20755279.2015.0107

152.Prusik Krzysztof, Prusik Katarzyna, Kozina ZhL, Iermakov SS. Features of physical development, physical preparedness and functional state of boys and girls - students of Polish higher educational establishments. Physical education of students, 2013;1:54-62.

153.Pryimakov AA, Eider E, Omelchuk EV . Stability of equilibrium in upright stance and voluntary motion control in athletes-shooters in the process of ready position and target shooting. Physical education of students, 2015;1:36-42. http://dx.doi.org/10.15561/20755279.2015.0106 
154.Prystupa TD. Effect of partial sports massage on blood pressure and heart rate. Physical education of students, 2013;6:55-60.

155.Pyatnickaya DV. Development of girl-students' physical qualities at extracurricular cheer-dance classes (cheer-dance show). Physical education of students, 2015;4:31-38. http://dx.doi.org/10.15561/20755279.2015.0405

156.Pyatnychuk GO. Assessment of speed and power abilities of the students during the weekly training cycles. Physical education of students, 2014;1:39-44.

157. Radzievskiy RM, Plisko VI. Law enforcers recognition level emerging threats based on physical appearance and behavior signs the enemy. Physical education of students, 2015;1:50-59. http://dx.doi.org/10.15561/20755279.2015.0108

158. Rastegar Hoseini, Fatemeh Ghasemi, Mahri Hoseini. Effect of 8 weeks of aerobic or resistance training on blood pressure in non-physical education male students. Physical education of students, 2014;1:64-68.

159. Robert Podstawski, Danuta Zwolinska, Renata Urbanska-Gizinska, Danuta Nowosielska-Swadzba. The effect of learning environment factors on biological development of first year students. Physical education of students, 2013;6:103-108.

160. Romanowska-Tolloczko Anna, Piwowarczyk Piotr. The assessment of difficulty of yacht sailing classes and students' global self-esteem. Physical education of students, 2015;3:79-83. http://dx.doi.org/10.15561/20755279.2015.0310

161. Romanowska-Tolloczko Anna. Emotional competencies of the forthcoming physiotherapists and physical education teachers. Physical education of students, 2014;5:70-73. http://dx.doi.org/10.15561/20755279.2014.0513

162. Roters T T. Physical improvement of students during interactive physical and aesthetic education. Physical education of students, 2013;4:72-77.

163. Rovniy AS, Lastochkin VM. Mechanisms of adaptation to intensive loads of 400 meters' hurdles runners at stage of initial basic training. Physical education of students, 2015;4:39-43. http://dx.doi.org/10.15561/20755279.2015.0406

164. Ryepko OA. Features and functionality of speed and power capabilities of elite climbers and various types of rock climbing. Physical education of students, 2013;6:60-66.

165. Saeed Jamshidi Far, Mirza Hossein Norouzi Kamareh. The effect of sleep deprivation on serum igg responses to aerobic activity in college student athletes. Physical education of students, 2014;6:90-95. http://dx.doi.org/10.15561/20755279.2014.0617

166. Sedova OO. The investigation of the level of preschool children with eyesight problems functional state. Physical education of students, 2013;2:54-59.

167. Semanychyn TM, Popel' SL. Professional portrait of future instructors for physical education of preschool. Physical education of students, 2015;1:60-66. http://dx.doi.org/10.15561/20755279.2015.0109

168. Sergienko VN. Complex estimation of development of power capabilities of students of higher educational establishments. Physical education of students, 2013;5:83-88.

169. Sergienko VN. Evaluation of integrated testing the maximum force of students aged 17-20 years. Physical education of students, 2013;4:77-82.

170. Sergienko VN. Morphological indicators of the female students of the 17-20 age group. Physical education of students, 2013;6:73-78.

171. Sergienko YP, Andreianov AM. Models of professional readiness of students of higher military schools of the Armed Forces of Ukraine. Physical education of students, 2013;6:66-73.

172. Shahram Gholamrezai, Mina Zali, Ramin Shabani, Rastegar Hoseini. Effect of 8 weeks of aerobic on body composition and blood pressure in postmenopausal women. Physical education of students, 2014;5:74-78. http://dx.doi.org/10.15561/20755279.2014.0514

173. Shalar OG, Strikalenko EA, Ivaschenko AN. Individual properties of personality as criterion of choice of style of game of tennis players. Physical education of students, 2013;2:69-74.

174. Shul'ga LM, Rudkovskaya TI. Estimation of competitive activity in synchronized swimming. Physical education of students, 2013;1:82-87.

175. Shypulo I P. Influence employment by improving aerobics on motor readiness of girls. Physical education of students, 2015;1:67-71. http://dx.doi.org/10.15561/20755279.2015.0110

176. Singh Virendra Kumar, Agashe Chandrakant D. Effect of information processing and depth perception upon throwing accuracy of basketball players. Physical education of students, 2015;2:37-42. http://dx.doi.org/10.15561/20755279.2015.0206

177. Skyrta OS. Conditional duel, as methodical reception of perfection to technical tactical preparedness in kickboxing, and its classification. Physical education of students, 2013;1:62-68.

178. Slavityak OS. The problem of search safe and effective method in reducing injuries in bodybuilding stage of specialized basic training. Physical education of students, 2014;6:63-68. http://dx.doi.org/10.15561/20755279.2014.0612

179. Smaylova SA. Evaluation of correction in shaping body mass women first adulthood with different personal features. Physical education of students, 2013;3:50-55. 
180. Sobko I N. Characteristics of competitive activity of qualified basketball with hearing impairment compare to qualified healthy basketball player. Physical education of students, 2013;4:82-87.

181.Sobko IN. The preparation for the year main competition teams in basketball with hearing impairments with innovative technologies. Physical education of students, 2014;5:30-37. http://dx.doi.org/10.15561/20755279.2014.0506

182. Sobyanin FI, Dudkina SG. About a competence and professional trade of specialists in the field of physical culture. Physical education of students, 2013;1:68-74.

183. Soronovich IM, Chaikovsky EV, Pilevskaya V. Features of functional support of competitive activity in sports dance given the differences prepared by partners. Physical education of students, 2013;6:78-88.

184. Sovenko SP, Budkevych HB, Lytvynchuk TV. Technical specifications of qualified sportswomen who specialize in race walking for $10 \mathrm{~km}$. Physical education of students, 2014;4:37-41.

185. Stetsenko AI. The highest achievements of Ukrainian powerlifting at international events during its origin and formation. Physical education of students, 2014;1:44-50.

186. Supilo IP. Biomechanical modeling of the physical training of girls during aerobic activities in non-school educational institutions. Physical education of students, 2014;6:73-76. http://dx.doi.org/10.15561/20755279.2014.0614

187. Surovov AA. Specialized Internet resources as interactive technology in the training of future teachers of physical training. Physical education of students, 2013;3:55-60.

188. Synytsya S V, Shesterova L E, Synytsya T O. Assessment of communicative abilities of students of pedagogical universities on the results of primary instruction on improving aerobics. Physical education of students, 2014;3:5661.

189. Tereschenko IA, Otsupok AP, Krupenio SV, Levchuk TM, Boloban VN. Evaluation of freshmen coordination abilities on practical training in gymnastics. Physical education of students, 2013;3:60-72.

190. Tereshchenko IA, Otsupok AP, Krupenya SV, Liauchuk TM, Boloban VN. Coordination training of sportsmen, specializing in sport kinds of gymnastic. Physical education of students, 2015;3:52-65. http://dx.doi.org/10.15561/20755279.2015.0307

191. Tereshchenko IA, Otsupok AP, Krupenya SV, Liauchuk TM, Boloban VN . Sensomotor coordination, theoretical and physical (motor) preparedness of first year students of higher educational institutions of physical education and sport. Physical education of students, 2013;6:88-96.

192. Tereshchuk MV. The system of world golf ranking among amateur players - WAGR. Physical education of students, 2014;6:69-72. http://dx.doi.org/10.15561/20755279.2014.0613

193. Tikhonova NV. Sale leisure activities of children and youth in out of school educational establishments of physical culture and sports destinations. Physical education of students, 2014;5:38-42. http://dx.doi.org/10.15561/20755279.2014.0507

194. Toporkov AN. The preparation of tourists to the ski sports tours in a limited time in order to prevent injuries and accidents. Physical education of students, 2014;4:42-48.

195. Tropin YM. Analysis of technical tactical training of highly skilled fighters of Greco-Roman wrestling. Physical education of students, 2013;2:59-63.

196. Tropin YM. Comparative analysis of technical and tactical preparedness Greco-Roman style wrestler at the Olympic Games-2008 and the Olympic Games-2012. Physical education of students, 2013;4:92-97.

197. Tsybul'ska VV. Self-appraisal adequacy of students' physical abilities of pedagogical specialties involved in various forms of education. Physical education of students, 2014;5:48-52. http://dx.doi.org/10.15561/20755279.2014.0509

198. Tsyganenko OI, Persheguba YaV, Paladina OL, Sklyarova NA, Oksamytnaya LF. Problem of inadequate food conduct of persons, engaged in fitness and during physical rehabilitation as a component of health-improvement fitness programs, way of its decision. Physical education of students, 2013;2:63-69.

199. Tyshchenko VA. Research of the role of self-consciousness on the efficiency of sportsmen rehabilitation. Physical education of students, 2013;4:87-92.

200. Usakovsky YO, Bova NI. Comparative analysis of motive activity with a ball and without in training of different playing lines of young footballers aged 11-15 years. Physical education of students, 2013;1:74-78.

201. Uskov SV. Formation of stress students in the process of notions of martial arts in high school. Physical education of students, 2013;5:88-93.

202. Vasilios Giovanis, Kiriakos Amoutzas, Efstathios Vasileiou, Efstathia Ramadani, Efthimios Badas. The diet of skiers with regard to the frequency of dinners. Physical education of students, 2013;6:96-103.

203. Vorfolomeeva LA. Individualization of training process as a leading construction of skiers' training component in preparation for higher achievements. Physical education of students, 2013;4:15-19.

204. Voronkov AV, Nikulin IN, Sobyanin FI. On the improvement of the control force readiness students engaged arm sport. Physical education of students, 2014;2:3-8. 
205.Wang Lihua, Zhang Wei Shou. Study results on estimation of non-specialized physical training university students in Hunan Province. Physical education of students, 2013;1:12-17.

206. Yaremenko WW. Research of kinematic characteristics of basic attacking technical action young wrestlers freestyle. Physical education of students, 2014;2:56-59.

207. Yurchyshyn YV. Modern information tools: their place in students' extra-curriculum and involvement of them in motor activity of health related orientation. Physical education of students, 2015;4:44-50. http://dx.doi.org/10.15561/20755279.2015.0407

208.Zaharova LV, Lyulina NV. Basis of integrated approach to sports and recreational activities of students of special medical groups. Physical education of students, 2014;1:17-22.

209.Zakorko IP. Use of employments on swimming in pulling in and restoration microcycles in the training process of the highly skilled sportsmen of the highly skilled heavy weight sambo wrestlers. Physical education of students, $2013 ; 1: 30-33$.

210.Zhula VP. Development of motive skills of students while making underarm pass during playing volleyball. Physical education of students, 2014;6:13-16. http://dx.doi.org/10.15561/20755279.2014.0603

211.Zuoziene IJ. Peculiarities of physical fitness and body composition of students engaged and not engaged in sports. Physical education of students, 2013;6:15-20.

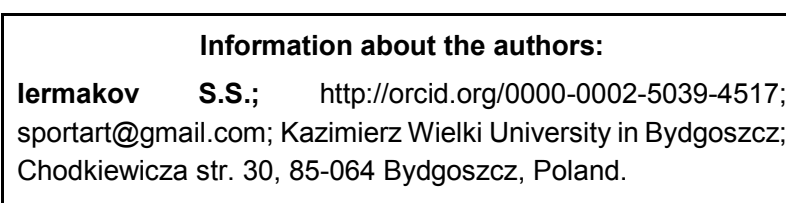

Cieślicka Mirosława; http://orcid.org/0000-0002-0407-2592; cudaki@op.pl; Kazimierz Wielki University in Bydgoszcz; Chodkiewicza str. 30, 85-064 Bydgoszcz, Poland.

Muszkieta Radosław; http://orcid.org/0000-0001-6057-1583; radek@muszkieta.com; Kazimierz Wielki University in Bydgoszcz; Chodkiewicza str. 30, 85-064 Bydgoszcz, Poland.

Cite this article as: Iermakov S.S., Cieślicka Mirosława, Muszkieta Radosław. Physical culture in life of EasternEuropean region students: modern state and prospects of development. Physical education of students, 2015;6:16-30. http://dx.doi.org/10.15561/20755279.2015.0603

The electronic version of this article is the complete one and can be found online at: http://www.sportpedu.org.ua/html/arhive-e.html

This is an Open Access article distributed under the terms of the Creative Commons Attribution License, which permits unrestricted use, distribution, and reproduction in any medium, provided the original work is properly cited (http://creativecommons.org/licenses/by/4.0/deed.en).

Received: 20.08 .2015

Accepted: 29.08.2015; Published: 10.09.2015 